Education + Training

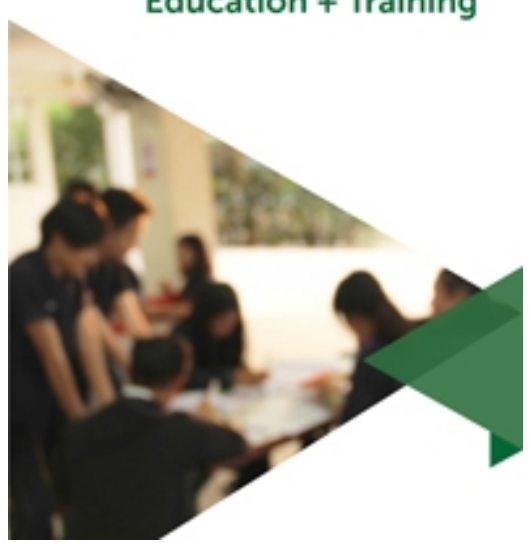

The gap in soft skills perceptions: A dyadic analysis

\begin{tabular}{|r|l|}
\hline Journal: & Education + Training \\
\hline Manuscript ID & ET-03-2019-0060.R2 \\
\hline Manuscript Type: & Research Paper \\
\hline Keywords: & soft skills, dyadic survey, employability \\
\hline \multicolumn{2}{l}{} \\
\end{tabular}

SCHOLARONE ${ }^{m}$ Manuscripts 


\title{
The gap in soft skills perceptions: A dyadic analysis
}

\begin{abstract}
Purpose: Previous studies have shown that soft skills play a significant role in applicants' employability and in the job search, recruitment, selection and hiring process. However, past research indicates a gap in perceptions of soft skills, between employees and employers. The present empirical research aims to explore this gap in perceptions and to suggest effective ways to resolve any mismatch. Demographical factors affecting these perceptions are also taken into consideration for the analysis.
\end{abstract}

Methodology: A quantitative research design has been applied. The survey undertaken, covers all three main sectors of employment (manufacturing, retail and services), with 151 employee-employer dyads around Greece participating in the survey. Paired sample $\mathrm{t}$-test, independent $\mathrm{t}$-test and One-way ANOVA were used to analyze the data.

Findings: The results show a gap between employees' and their subsequent employers' perceptions of employees' soft skills. Employees seem to regard their skills more highly than do their employers, whereas employers seem to consider employees as not properly equipped with the necessary soft skills. These findings are a worrying sign for business operations and suggest that difficulties in manager-employee co-operation can arise.

Practical Implications: This study has both theoretical and practical implications. It adds to the literature in human resources appraisal process by identifying soft skills perceived differently by employees and employers. It also highlights the reasons for that gap and makes suggestions for the enhancement of required skills.

Originality: The majority of previous studies in the field focus either on employees' or employers' perceptions, without comparing them. In addition, the few former studies attempt a comparison focused on students as employees or trainees, with no previous work experience. The current study focuses on employees whose work experience has already shaped perceptions of their skills and employability.

Paper type: Research paper

Keywords: soft skills, employability, dyadic survey 


\section{Introduction}

Currently innovation, intense competition, globalization and continuous technological change are trends that characterize business activities around the world (Van den Broeck et al., 2015; AbuJbara and Worley, 2018). The international labor market is constantly shifting, moving from an industrial economy to an information and office economy (Robles, 2012). New positions are created and new job descriptions produced, leading to additional requirements and the need to develop qualifications and extra skills. Many employee skills that were desirable in previous years are now considered obsolete and have been replaced (Van Emmerik et al., 2012; Pitan 2017). Thus, job seekers should be well equipped with a long set of up-to-date skills to deal with the demands of the complex global business environment.

Desirable skills in today's job market include both hard and soft skills (Laker and Powell, 2011). Hard skills are mainly academic and technical qualifications that are related to an employee's ability to accomplish a specific goal, activity, task or job (Robles, 2012). These skills are included in a CV and revolve around education, work experience, knowledge and professional skills, such as the ability to use computer programs (Cimatti, 2016). Employees need technical competencies to do their jobs, but these type of skills are not the only requirement for a successful career path. Soft skills not only complement hard skills nowadays, but are also considered essential for a job candidate (Clarke, 2017).

Moss and Tilly (2001, p. 44) defined soft skills as "skills, abilities, and traits that pertain to personality, attitude and behavior rather than to formal or technical knowledge". In the literature several sets of soft skills have been suggested, including in their majority listed communication, problem-solving, conflict resolution, goal setting and planning and task coordination (Muzio et al. 2007; Jolly, 2012; Robles, 2012; Mitchell et al., 2010, Stevens and Campion, 1999). This very combination of personal qualities and interpersonal skills makes individuals employable (Andrews and Higson, 2008) and enhances their performance (Turek and Perek-Bialas, 2013; Ibrahim et al., 2017). Such skills are not linked to academic proficiency and are intangible, personality-specific and difficult to prove (Rao, 2014).

In addition, previous research has indicated that graduates who have good social skills and attributes (i.e., soft skills) are more able to develop technical skills as well (Poon, 2012). Finch et al. (2013) placed social skills in the highest ranking in the list of crucial employability skills, whereas academic reputation (related to knowledge acquired) was in the lowest ranking. Deming (2015) presented evidence of growing demand for social skills over the last decades and noted that workers with high social skills trade tasks at a lower cost and earn a relatively higher wage in return. Despite the importance of soft skills, research in this field is limited. Perhaps because of the difficulty of measuring soft skills in the absence of an objective way to test them (Balcar, 2016; Bak et al., 2019).

Research up to now, highlights the presence of gaps and deficits between employer requirements for soft skills and the actual skills levels of employees or applicants (Rao, 2014; US Chamber of Commerce Foundation, 2016; Ramli et al., 2010; Hurrell, 2016; Stapleton, 2017). These gaps resulting from skills shortages and skills mismatches (Lippman et al., 2015; Seetha, 2014), are reflected in unemployment rates. For instance, in Greece, which has the highest rate of youth unemployment in Europe (55\%), 33\% of employers declare that they leave vacancies open/unfilled because applicants do not have the required skills (McKinsey report, 2012). Soft skills seem to be missing more frequently among applicants. More specifically employers often complain about 
applicants not having the necessary work ethic, verbal and non-verbal communication skills, willingness to participate or positive behavior (Robles, 2012).

Most past studies focused on the views of either job applicants or employers (Albandea and Giret, 2018; Wesley et al., 2017; Wickramasinghe and Perera, 2010; Finch et al. 2013; Taylor, 2016; Ramlan and Ngah, 2015). Oladokun and Gbadegesin (2017) indicated that further study is needed to address the perceptions of both employees and employers to ensure the results are devoid of bias. Brungardt (2011) proposed a 360-degree feedback perspective by recommending that data collection include graduates' supervisors, peers and direct reports, who would all evaluate the graduate's performance in terms of soft skills. By exploring the perception of employee-employer dyads, rather than the perception of only one party, a better understanding of the skill gap is achieved (Gibb, 2014). Thus, employees and their employers participated in the current empirical survey, in contrast to the literature in the field, which focuses on one of the two groups.

In addition, previous studies focusing on college students or graduates have found a gap between their skill levels and employers' skill requirements (Wesley et al., 2017; Wickramasinghe and Perera, 2010; Finch et al. 2013; Taylor, 2016; Teng et al., 2019). The current paper concentrates on critical soft skills required in the labor market and explores any discrepancy in employers' and employees' perceptions of employees' soft skill level. Those who have work experience better realize the importance of soft skills (Ziegler, 2007). Specifically, exposure to work situations can help applicants to develop understanding, self-efficacy and critical and reflective thinking (Knight and Yorke, 2002). Work exposure also improves soft skills and increases employees' self-confidence (McMurray et al., 2016).

The practical importance of this study is twofold: first to increase awareness among educational managers and employees of the importance of soft skills and second to reveal and assess the degree of any discrepancy in employer and employee perceptions. This paper empirically confirms the prevailing perception concerning the phenomenon of the "skills gap," which has been widely discussed in the academic literature (Stapleton, 2017; Teng et al., 2019; Chan, 2015). An identified gap could motivate further research on the causes of the gap and the ways it can be addressed. Variation in the perceptions of the two groups offers a significant opportunity to a) motivate employees to rethink their selfevaluation on a more objective basis, b) alert employees to develop their soft skills to close the gap and possibly increase their employability and success at work, c) encourage educational institutions to link education and training to current and future labor market needs, d) push employers to reconsider their employees' evaluations as they become closer to reality and e) assist employers to train their employees.

A discussion of the concept of soft skills and an overview of the literature concerning the employee-employer perception gap follows. Research methodology, data analysis and results are presented in the two subsequent parts. A discussion of the results is given in the fifth section of the paper, outlining the study's contribution to the literature and to the practitioner world. Finally, the limitations and future research directions are reported.

\section{Literature review}

In the literature many attempts to define soft skills have been conducted. These skills are considered a combination of personality traits, social graces, facility with language, 
personal habits, friendliness and optimism (Pandey and Pandey, 2015) or as goals, motivations and preferences (Heckman and Kautz, 2012). Different researchers also recognized different soft skills, like communication skills (Ilias et al. 2012; Singh and Jaykumar, 2019; Tempone et al. 2012), teamworking (Klibi and Oussii 2013; Freudenberg et al. 2011), leadership (Nusrat and Sultana, 2019; Truong and Laura, 2015), problemsolving skill (de Villiers, 2010), ability to practice ethical attitude (Singh and Jaykumar, 2019; Azim et al., 2010) or to work under pressure (Nusrat and Sultana, 2019). Robles (2012) proposed a list of the highest ranked soft skills which includes the following: communication ability, courtesy, flexibility, integrity, interpersonal skills, positive attitudes, responsibility, work ethic, professionalism and teamwork. Although there is no holistic accepted definition of soft skills or a consensus about the dimensions of the concept, researchers agree on its importance in almost every job and at every level of an organization (Grisi, 2014; Stapleton, 2017). Soft skills are interpersonal and widely applied (Chamorro-Premuzic et al., 2010), but they are very difficult to teach (Cimatti, 2016). This means that they can be transferred between different jobs and employment sectors and that they are aligned with the employee's general disposition and personality (Cox and King, 2006). However, soft skills are mainly needed for employees who interact with customers, customize products or services and handle customer complaints (Bailly, and Léné, 2012; Christou, 2002).

Soft skills are linked to employees' attitudes and behaviors and influence their ability to work effectively in the workplace, both individually and in collaboration with others. Specifically, Hawkins (1999) connected soft skills to a person's ability to find work, to succeed and to change jobs in a changing social, economic and political environment. Wesley et al. (2017, p. 81) highlights that "individuals who rank high in soft skills are generally the people that most employers want to hire, setting them apart from other potential employees". Overall, employers' and employees' perceptions of soft skills vary widely. Specifically, Orlando (2013), based on the opinions of 173 students with work experience who assessed the input received throughout their course of study and its usefulness in the company at which they work, concluded that the university's level of dedication to soft skills does not match corporate demands. Wesley et al. (2017) compared the importance of ranking of the seven core soft skills (experience, teamwork, communication, leadership, decision making/problem solving, self-management and professionalism) among college students, faculties and firms in the retailing and tourism industry. They observed a difference in the ranking among these three groups. Another survey conducted by Wickramasinghe and Perera (2010) explored employability skills in three main groups: graduates, university professors and employers. The examined groups ranked problem solving, self-confidence and teamwork as the most important skills for employability. However, the findings suggested that there are differences in the priority order among groups. When comparing the level of skills graduates possessed at the time of applying for their first job and the level of skills employers expected when selecting applicants, the study only identified a gap in problem-solving skills; employers' expectations were significantly higher than the level possessed by graduates. Along the same lines, Swiatek (2000) found evidence supporting differences in the importance graduates and employers give to employability skills overall. For instance, employers recognize social skills as the most critical factor for success in the workplace and believe that university graduates are not as prepared as they think they are. The aforementioned empirical research mainly focused on identifying the core soft skills and uncovering the discrepancy between employee and employer perception of skill ranking (Wesley et al., 2017; Wickramasinghe and Perera, 2010; Swiatek, 2000; Chamorro-Premuzic et al., 2010; 
Ramlan and Ngah, 2015). Another interesting and unexplored issue concerns the level of soft skills employees possess and exhibit in their job according to self-evaluation and employer assessment. Any identified gap may pose a major challenge for the two groups in understanding each other and working together to try to fill the gaps in desired skills.

According to Poon (2012), graduates may over-estimate their abilities, whereas employers have unrealistic expectations. The gap between employers' expectations and graduates' demonstration of knowledge, skills and attributes is broad. Similarly, Mayo (2016) found that MBA students rated themselves higher on each leadership competence than their peers did, supporting the notion that people tend to overestimate their own performance and skills.

The skills gap has led to a mismatch between employers' and job seekers' perceptions. Employers complain that they cannot find an employee with the appropriate skills and experience for the job position, and prospective employees are disappointed that the right job is not out there for them. The present study explores and compares employees' and employers' perceived level of soft skills in a variety of industries. Specifically, this paper examines how employees self-ranked their soft skills in relationship to employment and then compares their rankings to those of their employers. Thus, the first hypothesis is:

\section{H1: Employees have a higher perception of their degree of soft skills than their employers} do.

In addition, this study examined whether demographical factors such as gender and education affect employee and employer perceptions. Past studies have brought some evidence of gender differences in soft skills proficiency. Both men and women overestimate their performance (Lundeberg et al., 1994), but it has been found that women score higher than men on social perception and social judgment, which are measures of social skills (Sustein and Hastie, 2014). Women have also been found to have a higher mean score in four out of seven soft skills (leadership skills; teamwork skills; entrepreneurial skills; and values, ethics and professionalism); however, only the soft skill of values, ethics and professionalism has a significant difference between women and men (Ahmad, 2013). Furthermore, research supports that young women are better at soft skills required in the workplace; they are more prepared in the workplace and are more likely to have the soft skills required by businesses (OECD, 2015). A significant gender difference was also found in personality development and communication skills. Ismail et al. (2017) found that female students evaluated their skills as being higher as compared to their male peers. However, no significant difference has been found in management skills, leadership skills, writing skills and professional ethics based on gender.

The aforementioned research yielded different and contradictory findings concerning gender difference within soft skills. Lippman et al. (2015, p. 45) pointed though, that "there is not enough rigorous research on implications of applicants' gender on the utility of soft skills for workforce success". Driven by the lack of evidence and the inconsistencies in the results of prior studies, the second and third hypotheses of the present study are formed as follows:

\section{H2: Employees' perception of soft skills will be moderated by their gender.}

H3: Employee-employer perception of soft skills will be moderated by employees' gender.

On another point, it is crucial that the education system ensure that young people have at least the minimum skills needed for success in the workforce. Employers want to feel 
reassured that applicants can deploy their knowledge to solve problems, take initiative and communicate with team members, rather than just following prescribed routines (Aring, 2012). These soft skills are not taught but can be acquired through high-quality education (Aring, 2012). Thus, poor-quality education leads to a significant mismatch between labor market needs and the skills of graduates. Research supports that upper levels of education foster proficiency in soft skills (Lippman et al., 2015). The education received and the soft skills acquired through a range of academic activities are expected to give employees opportunities for gainful employment (Nauffal and Skulte-Ouaiss, 2018). A high school diploma works as a proxy for soft skills (Heckman and Rubinstein, 2001). Brunello and Rocco (2017) examined the educational system of seventeen countries and found that academic education provides higher basic skills proficiency (literacy and numeracy) than vocational education does. Vocational schools continue to have outdated curricula and tend to be too specialized in obsolete occupations, providing skills that are of little use in the labor market (Masson and Fetsi, 2007; Bartlett, 2013).

None of the mentioned studies empirically examined the relationship between soft skills possessed by employees and their educational level. Thus, this study hypothesizes the following:

H4: Employee perception of soft skills will be moderated by education.

H5: Employee-employer perception of soft skills will be moderated by employees' education.

\section{Methodological frame}

\subsection{Sample and Procedure}

Data for this quantitative study were collected through a survey among employees (and their corresponding employers at the time) enrolled in a training course in management and administration offered, by a vocational training institute. The training course, of a two months duration, took place in 2018. The data collection was conducted, the same year as well. It started towards the end of the training course and lasted for three months. Respondent participation to the survey was voluntary. For the purposes of the study, a convenience sample was used.

A two stage survey was used for the data collection. In the first stage, all the employees $(n=178)$ participating in the training course were asked to provide their perceptions of the level of soft skills they possess. The response rate for the first stage was $84.8 \%$ (151 participants). In the second stage, a pairing technique was used so as to come up with a matched sample and analyze, afterwards, the data collected as employee-employer pairs. Using the sample of 151 employees, the corresponding employer (supervisor), was contacted. The immediate supervisors or line managers of the employees were contacted. Thus, all the employers were in the low managerial level. Each employer was provided with the same questionnaire (as the one used in the first stage), for the evaluation of his employee's skills. More specifically, the employers were asked for their perceptions of the soft skills level of their employees. A coding system was used to match the employeeemployer responses. The survey reached a $100 \%$ response rate (all the 151 employers responded).

The dyads of employee-employer came from small and medium sized Greek firms, with $87.4 \%$ of them employing $0-4$ employees, $7.3 \%$ employing 5-25 employees and $5.3 \%$ employing over 25 employees. The sample came from a variety of organizations across all 


\subsection{Measures}

As mentioned above a survey questionnaire was used as the tool for the data collection. The same questionnaire was administered to both employees and employers, so as to investigate any existing gap between their perceptions of employees' soft skills. Both questionnaires included items, aiming to explore participants' perceptions of eight soft skills: a)communication, b)flexibility, c)interpersonal skills, d)positive attitude, e)professionalism, f)responsibility, g)team-working and h)work ethic (Robles, 2012).

After conducting a thorough literature review, the variables, to be used, were specified and the scales for the survey questionnaire were created, based on the description of soft skills by Muzio et al. (2007) and Robles (2012). Each soft skill was operationalized with a specific description and a number of representative items was linked to each variable, based on the literature (Table I). The soft skills items numbered 56 in total. The questionnaire also, included a number of questions on employees' socio-demographic characteristics, such as gender and education. These characteristics were used so as to aid in explaining the existing perception gaps.

Employees were asked to complete a self-assessment of their soft skills, stressing the level up to which they possessed each skill. Employers on the other hand, assessed the extent to which their employees possessed each of these soft skills. A Likert type scale was used for both questionnaires, where 1 represented "strongly disagree" and 7 represented "strongly agree". A pilot survey was conducted with a small group of employee-employer dyads to test the accuracy of the questionnaire. The pilot verified that the meaning the participants assign to each question matched the intended meaning and that questions were not ambiguous. Modifications were made to the items of the questionnaires, including semantic changes, following the pilot survey. The final version of the questions was also cross-checked by academics in the field.

Table I: Measures: items and reliability estimates

\begin{tabular}{|c|c|l|l|c|c|}
\hline Variable & $\begin{array}{l}\text { Number } \\
\text { of items }\end{array}$ & \multicolumn{1}{|c|}{$\begin{array}{c}\text { Definition } \\
\text { (Muzio et al., 2007; Robles, 2012) }\end{array}$} & Sample item & $\begin{array}{c}\text { Cronbach's } \\
\text { alpha }\end{array}$ & $\begin{array}{c}\text { Bibliographical source of } \\
\text { variable }\end{array}$ \\
\hline Communication & 8 & $\begin{array}{l}\text { ability to convey complex ideas } \\
\text { orally, in writing, presenting and } \\
\text { listening }\end{array}$ & $\begin{array}{l}\text { I ask questions in order to } \\
\text { understand the instructions } \\
\text { and opinions of others }\end{array}$ & $\begin{array}{l}\text { EE=0.830 } \\
\text { ER =0.875 }\end{array}$ & $\begin{array}{c}\text { Chamorro-Premuzic et } \\
\text { al., 2010; Ilias et al. 2012; } \\
\text { Singh } \\
\text { and Jaykumar, }\end{array}$ \\
\hline
\end{tabular}

three main sectors of employment - namely merchandising, manufacturing and services. In more detail, the dyads of employees-employers came from Retail Trade $41.7 \%$, Food Service Industry - HoReCa (Hotel Restaurant Cafe) 18.5\%, Personal Service Activities 14.6\%, Manufacturing \& Wholesales $12.6 \%$ and Health, Education \& Cultural Activities $12.6 \%$.

Of the employees participating in the survey, $62.9 \%$ were female and $37.1 \%$ were male. The majority of the respondents (56.2\%) were married. Regarding their age, middle-aged employees predominated: with $28.4 \%$ under 34 years, $39.8 \%$ between $35-44$ years old, $17.9 \%$ between $45-54$ years old and $13.9 \%$ over 55 years old. With respect to education level $36.4 \%$ were highly educated (holding a university degree), $40.4 \%$ had upper secondary or post education and $23.2 \%$ had lower secondary education. In addition, all respondents had previous work experience. A total of $56.9 \%$ had a good or excellent command of information technology, and $50.9 \%$ had good or excellent knowledge of a

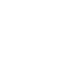


2019; Robles, 2012; Tempone et al. 2012; Blades et al., 2012; de Villiers, 2010; Succi \& Wieandt, 2019; Freudenberg et al. 2011; Klibi and Oussii 2013; Bak et al., 2019; Seetha, 2014; Andrews \& Higson, 2008; Azim et al., 2010; Bancino \& Zevalkink, 2007

Robles, 2012; Bak et al., 2019; Balaji \& Somashekar 2009; Andrews \& Higson, 2008; Bancino \& Zevalkink, 2007

Chamorro-Premuzic et al., 2010; Singh and Jaykumar, 2019; Robles, 2012; Blades et al., 2012; Andrews \& Higson, 2008; Bancino \& Zevalkink, 2007 Bak et al., 2019; Robles, 2012; Seetha, 2014 Chamorro-Premuzic et al., 2010; Singh and Jaykumar, 2019; Robles, 2012; Andrews \& Higson, 2008; Azim et al., 2010

Robles, 2012; Andrews \& Higson, 2008; Gewertz, 2007

Chamorro-Premuzic et al., 2010; Azim et al., 2010; Ilias et al. 2012; Klibi and Oussii 2013; Freudenberg et al. 2011; Singh and Jaykumar, 2019; Robles, 2012; Blades et al., 2012; de Villiers, 2010; Succi and Wieandt, 2019; Bak et al., 2019; Seetha, 2014; Bancino \& Zevalkink, 2007

Singh and Jaykumar, 2019; Robles, 2012; de Villiers, 2010; Klibi and Oussii, 2013; Gewertz, 2007; Azim et al., 2010

Note: $\mathrm{EE}=$ employee, $\mathrm{ER}=$ employer

Construct reliability was estimated with the internal consistency method using the Cronbach alpha $(\alpha)$ coefficient; the most common method for reliability analysis in similar studies. A Cronbach $\alpha$ ranging from 0.77 to 0.92 was obtained for employees, and a value within 0.71 and 0.89 was obtained for employers (Table I). These results are above the cut-off value of 0.70 , suggesting that the constructs have adequate internal consistency (Nunnally, 1978). 


\section{Results}

The present study compares the level of skills, employers consider their employees to have, with employees' self-assessments on the level of the same skills. To compare the two groups' perceptions on the same soft skills descriptive statistics (mean differences between the two groups) have been employed. Paired t-test has been used to identify statistical difference between the matched pairs. Independent samples t-test and OneWay ANOVA, have been used to compare the means of soft skills perceptions, among employee subgroups with different characteristics (two and three subgroups accordingly).

Results from employee self-assessments indicate a mean score of more than 5.5 (on a Likert scale of 7 points) for each one of the eight soft skills (communication, flexibility, interpersonal skills, positive attitude, professionalism, responsibility, team-working, work ethic) (Table II). Employees tend to assign themselves higher than average scores for these skills, reflecting a high level of confidence. Professionalism seems to have the highest mean score (6.16), whereas communication has the lowest mean (5.58), followed by interpersonal skills (5.64). On the other hand, the mean scores reflecting employers' perceptions, show a medium level of satisfaction with all eight soft skills; all skills had a mean score above 5.1, but no more than 5.47. Namely, the employees' ratings start higher than the employers' ratings. What is more interesting, is that employees' ratings start above the highest rating given by the employers. Thus, a gap in perceptions of soft skills is identified among employees and employers, ranging from 0.41 (in interpersonal skills and in communication) to 0.69 (in professionalism). The gaps between employer and employee perceptions are negative (employers' scores are lower than employees' scores), which indicates that employees' soft skills levels do not meet their employers' expectations (Figure I). In addition, employers' perceptions appear to have greater standard deviations for each soft skill in comparison to employees' perceptions' standard deviations. This implies that employees tend to provide answers towards specific values of each variable-positive values as it appears; indicating again a optimistic self-view.

A comparison of the employees' self-perceptions and employers' perceptions of the employees' soft skills is of particular interest (Table II). The paired samples statistics were used to highlight the differences between employers' and employees' perceptions of soft skills. Paired samples t-test used to access the significance of the mean difference (gap) in perceptions. A statistically significant difference between the average ratings provided by the two groups exists. A result which confirms Hypothesis (H1). In addition, the average ratings for each of the eight soft skills, show that employee and employer perceptions differ significantly $(\mathrm{p}<0.05)$ at a 0.001 confidence level.

Table II: Paired comparisons on difference scores

\begin{tabular}{|l|c|c|c|c|c|}
\hline \multicolumn{1}{|c|}{ Variable } & Employee & Employer & $\begin{array}{c}\text { Gap between } \\
\text { employee- employer } \\
\text { perception }\end{array}$ & t value & p value \\
\cline { 2 - 6 } & Mean & Mean & Mean Difference & & \\
\hline Communication & $5.58(0.70)^{*}$ & $5.17(1.17)$ & 0.41 & 3.91 & 0.00 \\
\hline Flexibility & $5.71(0.62)$ & $5.19(0.82)$ & 0.52 & 7.30 & 0.00 \\
\hline Interpersonal skills & $5.64(0.58)$ & $5.23(0.76)$ & 0.41 & 5.70 & 0.00 \\
\hline Positive Attitude & $5.75(0.66)$ & $5.29(0.81)$ & 0.46 & 5.71 & 0.00 \\
\hline Professionalism & $6.16(0.86)$ & $5.47(0.97)$ & 0.69 & 7.57 & 0.00 \\
\hline
\end{tabular}




\begin{tabular}{|l|l|l|l|l|l|}
\hline Responsibility & $5.73(0.77)$ & $5.26(0.89)$ & 0.47 & 5.43 & 0.00 \\
\hline Teamworking & $5.76(0.74)$ & $5.29(0.84)$ & 0.47 & 5.48 & 0.00 \\
\hline Work Ethic & $5.74(0.65)$ & $5.31(0.77)$ & 0.43 & 5.62 & 0.00 \\
\hline
\end{tabular}

${ }^{*}$ standard deviation in brackets

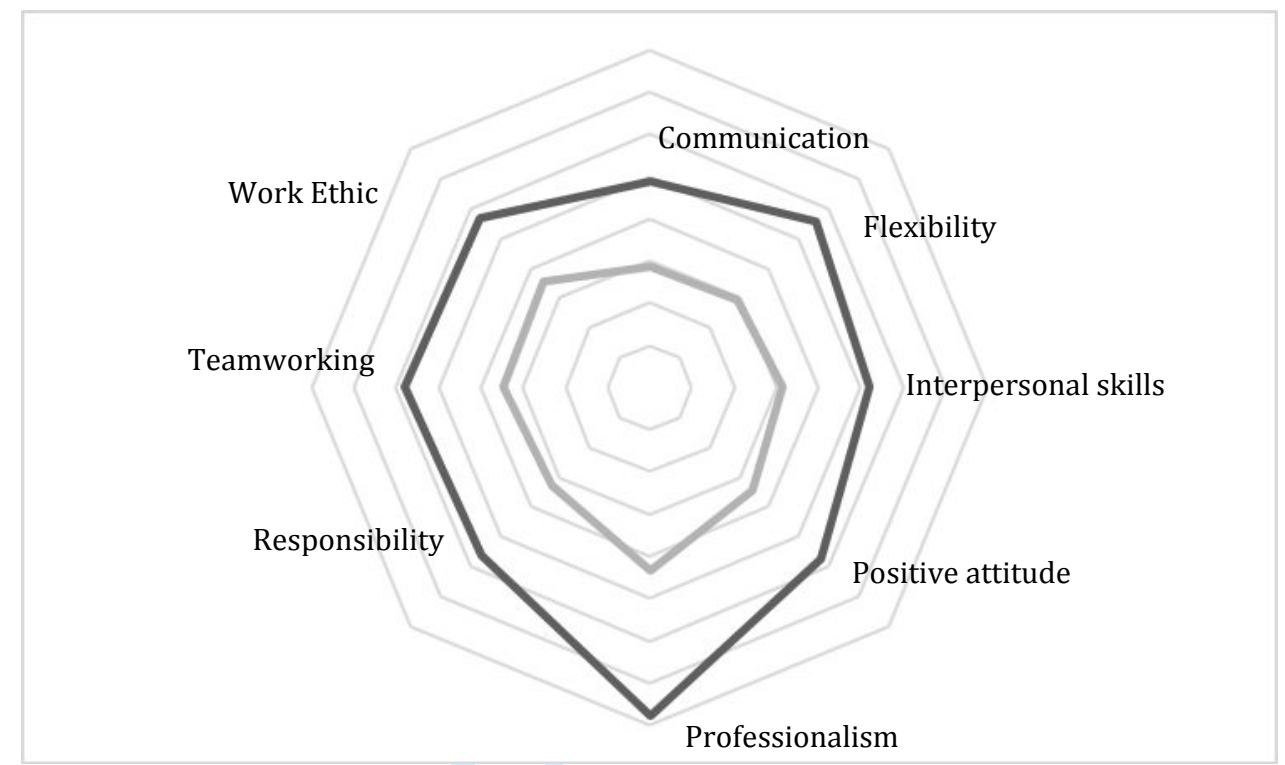

Figure I: Comparison between employee and employer perception Note: black line: employees' perception, grey line: employer perception

As far as, the employee sample is concerned, an independent sample t-test was performed to examine the differences between male and female employees' perceptions (Table III). Female employees were found to report higher levels of soft skills as compared with their male peers, with the mean difference of perceptions, between the two genders, ranging from 0.11 to 0.31 . The results were significant $(\mathrm{p}<0.05)$ for all variables, with the exception of communication, team-working and positive attitude, at $a=0.05$ level of confidence. Thus, the second hypothesis (H2), that there is a significant gender difference in the employees' perceptions of their soft skills, is partially and overall supported.

Table III: Employee perceptions differences based on gender

\begin{tabular}{|l|c|c|c|c|c|}
\hline \multirow{2}{*}{ Variable } & Male Employee & Female Employee & $\begin{array}{c}\text { Mean } \\
\text { Difference }\end{array}$ & t value & p value \\
\cline { 2 - 5 } & Mean & Mean & 0.23 & -1.922 & 0.06 \\
\hline Communication & $5.43(0.72)^{*}$ & $5.66(0.68)$ & 0.22 & -2.214 & 0.03 \\
\hline Flexibility & $5.57(0.62)$ & $5.79(0.61)$ & 0.26 & -2.762 & 0.01 \\
\hline Interpersonal skills & $5.48(0.54)$ & $5.74(0.58)$ & 0.11 & -1.214 & 0.23 \\
\hline Positive Attitude & $5.67(0.66)$ & $5.78(0.66)$ & 0.31 & -2.196 & 0.03 \\
\hline Professionalism & $5.96(0.93)$ & $6.27(0.80)$ & 0.23 & -2.027 & 0.04 \\
\hline Responsibility & $5.58(0.76)$ & $5.81(0.69)$ & 0.20 & -1.709 & 0.09 \\
\hline Teamworking & $5.63(0.78)$ & $5.83(0.71)$ & 0.25 & -2.443 & 0.02 \\
\hline Work Ethic & $5.57(0.62)$ & $5.82(0.65)$ & & &
\end{tabular}

Results also show that employers, as well, register significantly higher soft skills' scores for female than for male employees (Table IV). Employers seem to perceive women to have significantly more developed soft skills compared to men, which is in line with employees perceptions. However, again employers rate employees' soft skills lower compared to employees' self-ratings. The negative gaps (when employers perceptions are lower than employee perceptions) reach significantly higher levels for men (ranging from 0.57 to 0.87 ) than for women (ranging from 0.21 to 0.56 ). Concerning male employees, the highest negative gap is observed for professionalism (0.87), followed by 
communication skills (0.72). In the case of women, the highest negative gap is also observed for professionalism (0.56), followed by flexibility (0.39). Results support the third hypothesis (H3), that there is a significant gender difference in the employeeemployer perceptions of employees' soft skills $(4.33<\mathrm{t}<5.74$, for male and $1.50<\mathrm{t}<5.52$, $\mathrm{p}<0.05)$. This does not hold though, for communication as a soft skill for females; where a non significant difference exists between employee's and employer's perceptions.

TableI IV: Comparison between employee and employer perception by gender

\section{*standard deviation in brackets}

Note: $\mathrm{EE}=$ employee, $\mathrm{ER}=$ employer

When controlling, employees' self-ratings of soft skills, for employee educational level, results reveal even more differences (Table V). Three categories of educational level were used for purposes of this study: a) lower secondary education, b) upper secondary or post education and c) up to tertiary education. One-way ANOVA analysis is used for the comparison of means of the three employee groups (based on their educational level).

\begin{tabular}{|c|c|c|c|c|c|c|c|c|c|c|}
\hline Variable & $\begin{array}{l}\text { Male EE } \\
\text { (mean) }\end{array}$ & $\begin{array}{c}\text { Male ER } \\
\text { (mean) }\end{array}$ & $\begin{array}{c}\text { Mean } \\
\text { Differenc } \\
\mathrm{e}\end{array}$ & $\begin{array}{c}\text { t } \\
\text { valu } \\
\mathrm{e}\end{array}$ & $\begin{array}{c}\mathbf{p} \\
\text { valu } \\
\mathrm{e}\end{array}$ & $\begin{array}{l}\text { Female EE } \\
\text { (mean) }\end{array}$ & $\begin{array}{l}\text { Female ER } \\
\text { (mean) }\end{array}$ & $\begin{array}{c}\text { Mean } \\
\text { Differenc } \\
\mathrm{e}\end{array}$ & $\begin{array}{c}\mathrm{t} \\
\text { valu } \\
\mathrm{e}\end{array}$ & $\begin{array}{c}\mathbf{p} \\
\text { valu } \\
\mathbf{e} \\
\end{array}$ \\
\hline $\begin{array}{l}\text { Communicatio } \\
\mathrm{n}\end{array}$ & $\begin{array}{c}5.43 \\
(0.72)^{*}\end{array}$ & $\begin{array}{c}4.71 \\
(0.80)\end{array}$ & 0.72 & 5.34 & $\begin{array}{c}0.00 \\
0\end{array}$ & $5.66(0.68)$ & $5.45(1.27)$ & 0.21 & 1.50 & $\begin{array}{c}0.13 \\
0\end{array}$ \\
\hline Flexibility & $\begin{array}{c}5.57 \\
(0.62) \\
\end{array}$ & $\begin{array}{c}4.86 \\
(0.80) \\
\end{array}$ & 0.71 & 5.74 & $\begin{array}{c}0.00 \\
0 \\
\end{array}$ & $5.79(0.61)$ & $5.40(0.77)$ & 0.39 & 4.78 & $\begin{array}{c}0.00 \\
0\end{array}$ \\
\hline $\begin{array}{l}\text { Interpersonal } \\
\text { skills }\end{array}$ & $\begin{array}{c}5.48 \\
(0.54)\end{array}$ & $\begin{array}{c}4.91 \\
(0.71)\end{array}$ & 0.57 & 5.04 & $\begin{array}{c}0.00 \\
0\end{array}$ & $5.74(0.58)$ & $5.43(0.73)$ & 0.31 & 3.38 & $\begin{array}{c}0.00 \\
1\end{array}$ \\
\hline $\begin{array}{l}\text { Positive } \\
\text { Attitude } \\
\end{array}$ & $\begin{array}{c}5.67 \\
(0.66) \\
\end{array}$ & $\begin{array}{c}4.98 \\
(0.81) \\
\end{array}$ & 0.69 & 4.96 & $\begin{array}{c}0.00 \\
0 \\
\end{array}$ & $5.78(0.66)$ & $5.48(0.76)$ & 0.30 & 3.33 & $\begin{array}{c}0.00 \\
1\end{array}$ \\
\hline $\begin{array}{l}\text { Professionalis } \\
\mathrm{m}\end{array}$ & $\begin{array}{c}5.96 \\
(0.93)\end{array}$ & $\begin{array}{c}5.09 \\
(1.02)\end{array}$ & 0.87 & 5.23 & $\begin{array}{c}0.00 \\
0\end{array}$ & $6.27(0.80)$ & $5.71(0.87)$ & 0.56 & 5.52 & $\begin{array}{c}0.00 \\
0\end{array}$ \\
\hline Responsibility & $\begin{array}{c}5.58 \\
(0.76)\end{array}$ & $\begin{array}{c}4.93 \\
(0.86)\end{array}$ & 0.65 & 4.60 & $\begin{array}{c}0.00 \\
0\end{array}$ & $5.81(0.68)$ & $5.48(0.84)$ & 0.33 & 3.29 & $\begin{array}{c}0.00 \\
1\end{array}$ \\
\hline Teamworking & $\begin{array}{c}5.63 \\
(0.78) \\
\end{array}$ & $\begin{array}{c}4.98 \\
(0.78)\end{array}$ & 0.65 & 4.93 & $\begin{array}{c}0.00 \\
0\end{array}$ & $5.83(0.71)$ & $5.49(0.82)$ & 0.34 & 3.20 & $\begin{array}{c}0.00 \\
2\end{array}$ \\
\hline Work Ethic & $\begin{array}{c}5.57 \\
(0.62) \\
\end{array}$ & $\begin{array}{c}4.99 \\
(0.80) \\
\end{array}$ & 0.58 & 4.33 & $\begin{array}{c}0.00 \\
0\end{array}$ & $5.82(0.64)$ & $5.50(0.69)$ & 0.32 & 3.68 & $\begin{array}{c}0.00 \\
0\end{array}$ \\
\hline
\end{tabular}

Employees with undergraduate degrees differ considerably, from those with upper secondary or post education, and from those with lower secondary education, in terms of the soft skills they believe they possess. In particular, employees with tertiary education, register higher scores for all soft skills (above 5.80), compared to the other two educational groups. Employees seem to evaluate their soft skills higher, as the educational level increases. Moreover, employees of all educational levels, report a significantly high score for professionalism. 
Table V: Employees' perceptions of soft skills by educational level (One-way ANOVA analysis)

\begin{tabular}{|l|c|c|c|c|c|}
\hline \multirow{2}{*}{ Variable } & $\begin{array}{c}\text { Employees with } \\
\text { lower secondary } \\
\text { education }\end{array}$ & $\begin{array}{c}\text { Employees with } \\
\text { upper secondary or } \\
\text { post education }\end{array}$ & $\begin{array}{c}\text { Employees with } \\
\text { tertiary education }\end{array}$ & \multirow{2}{*}{ F value } & \multirow{2}{*}{} \\
\cline { 2 - 5 } & Mean & Mean & Mean & & \\
\hline Communication & $5.34(0.65)$ & $5.48(0.72)$ & $5.84(0.65)$ & 7.002 & 0.001 \\
\hline Flexibility & $5.45(0.57)$ & $5.68(0.65)$ & $5.90(0.58)$ & 6.251 & 0.002 \\
\hline Interpersonal skills & $5.47(0.60)$ & $5.60(0.54)$ & $5.80(0.59)$ & 4.190 & 0.017 \\
\hline Positive Attitude & $5.58(0.71)$ & $5.70(0.63)$ & $5.89(0.64)$ & 2.997 & 0.050 \\
\hline Professionalism & $5.75(0.91)$ & $6.15(0.93)$ & $6.42(0.65)$ & 7.034 & 0.001 \\
\hline Responsibility & $5.42(0.76)$ & $5.70(0.71)$ & $5.94(0.65)$ & 8.830 & 0.003 \\
\hline Teamworking & $5.50(0.68)$ & $5.70(0.80)$ & $5.98(0.76)$ & 5.513 & 0.005 \\
\hline Work Ethic & $5.49(0.64)$ & $5.71(0.65)$ & $5.90(0.61)$ & 4.982 & 0.008 \\
\hline
\end{tabular}

*standard deviation in bracket

Finally, the lowest score is reported for the communication skills (5.34), by employees with lower secondary education. The results support the fourth hypothesis (H4), which assumes a significant difference $(\mathrm{p}<0.05)$ in employees' perceptions, of all their soft skills, based on their educational level. F-value ranges from 2.997 to 8.830 for the different soft skills, always with a p-value $<0.05$.

Based on the paired t-tests, run for each educational level, the findings also reveal a significant difference between the employee and the employer perceptions of employee soft skills, when taking into consideration the employees' educational level $(3.72<\mathrm{t}<5.90$ for lower level education, $2.38<\mathrm{t}<3.71$ for the upper or secondary education and $2.75<\mathrm{t}<5.12$ for the tertiary educational level, $\mathrm{p}<0.05$ ). The negative gaps are significantly lower for employees with tertiary education (ranging from 0.26 to 0.65 ) than for employees with upper secondary or post education (ranging from 0.43 to 0.72 ) or lower secondary education (ranging from 0.41 to 0.65 ), for almost all soft skills. Professionalism seems to be the soft skill for which the greater gaps are observed (ranging from 0.62 to 0.72) (Tavle VI). 
Table VI: Comparison between employee and employer perceptions by educational level

\begin{tabular}{|c|c|c|c|c|c|c|c|c|c|c|c|c|c|c|c|}
\hline Variable & $\begin{array}{c}\text { Lower } \\
\text { EE } \\
\text { (mean) }\end{array}$ & $\begin{array}{c}\text { lower } \\
\text { ER } \\
\text { (mean) }\end{array}$ & $\begin{array}{c}\text { Mean } \\
\text { difference }\end{array}$ & $\begin{array}{c}\mathrm{t} \\
\text { value }\end{array}$ & $\begin{array}{c}\mathbf{p} \\
\text { value }\end{array}$ & $\begin{array}{c}\text { Upper } \\
\text { EE } \\
\text { (mean) }\end{array}$ & $\begin{array}{c}\text { Upper } \\
\text { ER } \\
\text { (mean) }\end{array}$ & $\begin{array}{c}\text { Mean } \\
\text { difference }\end{array}$ & $\begin{array}{c}\text { t } \\
\text { value }\end{array}$ & $\begin{array}{c}\text { p } \\
\text { value }\end{array}$ & $\begin{array}{c}\text { Tertiary } \\
\text { EE } \\
\text { (mean) }\end{array}$ & $\begin{array}{c}\text { Tertiary } \\
\text { ER } \\
\text { (mean) }\end{array}$ & $\begin{array}{c}\text { Mean } \\
\text { difference }\end{array}$ & $\begin{array}{c}\text { t } \\
\text { value }\end{array}$ & $\begin{array}{c}p \\
\text { value }\end{array}$ \\
\hline Communication & $\begin{array}{c}5.34 \\
(0.64)^{*}\end{array}$ & $\begin{array}{c}4.93 \\
(1.87)\end{array}$ & 0.41 & 5.90 & 0.000 & $\begin{array}{c}5.48 \\
(0.72)\end{array}$ & $\begin{array}{c}5.01 \\
(0.83)\end{array}$ & 0.47 & 2.84 & 0.016 & $\begin{array}{c}5.84 \\
(0.65)\end{array}$ & $\begin{array}{c}5.51 \\
(0.81)\end{array}$ & 0.33 & 2.76 & 0.009 \\
\hline Flexibility & $\begin{array}{c}5.45 \\
(0.56) \\
\end{array}$ & $\begin{array}{c}4.80 \\
(0.68)\end{array}$ & 0.65 & 5.80 & 0.000 & $\begin{array}{c}5.68 \\
(0.64)\end{array}$ & $\begin{array}{c}5.11 \\
(0.82)\end{array}$ & 0.57 & 3.71 & 0.003 & $\begin{array}{c}5.90 \\
(0.57)\end{array}$ & $\begin{array}{c}5.57 \\
(0.78)\end{array}$ & 0.33 & 3.60 & 0.001 \\
\hline $\begin{array}{l}\text { Interpersonal } \\
\text { skills }\end{array}$ & $\begin{array}{c}5.47 \\
(0.60)\end{array}$ & $\begin{array}{c}4.96 \\
(0.65)\end{array}$ & 0.51 & 4.40 & 0.000 & $\begin{array}{c}5.60 \\
(0.54)\end{array}$ & $\begin{array}{c}5.14 \\
(0.76)\end{array}$ & 0.46 & 2.69 & 0.021 & $\begin{array}{c}5.80 \\
(0.58)\end{array}$ & $\begin{array}{c}5.54 \\
(0.74)\end{array}$ & 0.26 & 2.75 & 0.010 \\
\hline $\begin{array}{l}\text { Positive } \\
\text { Attitude }\end{array}$ & $\begin{array}{c}5.58 \\
(0.71)\end{array}$ & $\begin{array}{c}4.93 \\
(0.62)\end{array}$ & 0.65 & 5.05 & 0.000 & $\begin{array}{c}5.70 \\
(0.63)\end{array}$ & $\begin{array}{c}5.24 \\
(0.87)\end{array}$ & 0.46 & 2.45 & 0.032 & $\begin{array}{c}5.89 \\
(0.63)\end{array}$ & $\begin{array}{c}5.60 \\
(0.73)\end{array}$ & 0.29 & 3.73 & 0.001 \\
\hline Professionalism & $\begin{array}{c}5.75 \\
(0.90)\end{array}$ & $\begin{array}{c}5.13 \\
(0.96)\end{array}$ & 0.62 & 4.73 & 0.000 & $\begin{array}{c}6.15 \\
(0.93)\end{array}$ & $\begin{array}{c}5.43 \\
(1.05)\end{array}$ & 0.72 & 2.58 & 0.025 & $\begin{array}{c}6.42 \\
(0.65)\end{array}$ & $\begin{array}{c}5.77 \\
(0.81)\end{array}$ & 0.65 & 5.12 & 0.000 \\
\hline Responsibility & $\begin{array}{c}5.42 \\
(0.76)\end{array}$ & $\begin{array}{c}4.92 \\
(0.69)\end{array}$ & 0.50 & 3.87 & 0.000 & $\begin{array}{c}5.70 \\
(0.70)\end{array}$ & $\begin{array}{c}5.27 \\
(1.00)\end{array}$ & 0.43 & 3.10 & 0.010 & $\begin{array}{c}5.94 \\
(0.64)\end{array}$ & $\begin{array}{c}5.52 \\
(0.78)\end{array}$ & 0.42 & 3.56 & 0.001 \\
\hline Teamworking & $\begin{array}{c}5.50 \\
(0.67)\end{array}$ & $\begin{array}{c}4.99 \\
(0.76)\end{array}$ & 0.51 & 3.72 & 0.000 & $\begin{array}{c}5.70 \\
(0.79)\end{array}$ & $\begin{array}{c}5.20 \\
(0.84)\end{array}$ & 0.50 & 2.38 & 0.036 & $\begin{array}{c}5.98 \\
(0.66)\end{array}$ & $\begin{array}{c}5.61 \\
(0.80)\end{array}$ & 0.37 & 3.06 & 0.004 \\
\hline Work Ethic & $\begin{array}{c}5.49 \\
(0.63)\end{array}$ & $\begin{array}{c}5.00 \\
(0.66)\end{array}$ & 0.49 & 4.71 & 0.000 & $\begin{array}{c}5.71 \\
(0.65)\end{array}$ & $\begin{array}{c}5.23 \\
(0.84)\end{array}$ & 0.48 & 2.58 & 0.025 & $\begin{array}{c}5.90 \\
(0.60)\end{array}$ & $\begin{array}{c}5.61 \\
(0.65)\end{array}$ & 0.29 & 3.75 & 0.001 \\
\hline
\end{tabular}

standard deviation in bra

Note: $\mathrm{EE}=$ employee, $\mathrm{ER}=$ employer 


\section{Conclusions and practical implications}

Human Resource (HR) managers running the recruitment process, are concerned with applicants' soft skills and attitudes, apart from hard technical skills. Managers and employers seek employees who possess that essential set of skills, so as to respond well to their complicated work responsibilities. Nowadays, employees have more autonomy in their work, make more decisions and interact with customers and clients more often, than employees in the past used to. Employees, in the past, had mainly repetitive tasks to perform (Brungardt, 2011). These days, soft skills highly affect employability and career progression (Nickson et al., 2012; Orlando, 2013; Nilsson, 2010). Thus, employees should be well equipped with soft skills to increase their chances of getting employed, enhance their individual productivity and succeed in the workforce (Finch et al., 2013; Seetha, 2014).

Seminal studies in the field, support that most people tend to evaluate themselves positively and high enough (Mayo, 2016; Poon, 2012; Wickramasinghe and Perera, 2010). The findings of the present research confirm this and add to previous studies by indicating significant differences between employees' and employers' perceptions regarding employees' soft skills. Employees seem to overestimate their soft skills and believe that they possess them in a higher level than their employers perceive. The greatest difference between employee and employer perception can be seen for professionalism, whereas the smallest margin of difference is reported for interpersonal skills and communication. Based on the results and according to their employers, employees are not properly equipped with the necessary soft skills to perform effectively in the workplace. Employees' proficiency levels are inconsistent with the levels their employers require, raising questions regarding how well-equipped graduates are and the extent to which they are able to implement their soft skills to the workplace. Thus, based on these findings, employees' efforts to develop themselves should be more focused on the soft skills for which they score lower.

Findings regarding the impact of employee gender and employee educational level on the perceived soft skills levels, aid in the identification of these groups that need more guidance and training and in the identification of the specific soft skills needed for each educational level. Therefore, male employees seem to be in need of training, as women outperform them in all the soft skills examined, based on self- and employer's evaluations. Professionalism still appears to be that soft skill which employees (no matter the gender) perceive they have it in higher levels, than their corresponding employers believe. These findings add to the findings by Arraj (2018), who empirically examined the level of professionalism among civil servants in Lebanon, finding a low level of professionalism among them. Professional employees dress appropriately for the job, manage their time effectively, speak politely and positively and show initiative. This kind of soft skills is not easy to be reinforced and tends to take years of experience to be developped. Social perception rather than gender difference, could be the reason though (Sustein and Hastie, 2014). Gender differences in the soft skills, seem to come from employers' expectations rather than genetics. Men may respond to the rising price of such skills by increasing their investment in them (Kato and Kodama, 2017). However, "these endowment gender differences, combined with rising value of such skills ... will result in narrowing gender gap in wage and in more women in the workplace"( Kato and Kodama (2017, p. 10).

In terms of educational levels, employee-employer perception gaps are significantly lower for employees with tertiary education than for employees with upper secondary or 
post education or lower secondary education. This likely means that the level and type of competence that comes from universities, is more similar to workplace exposure, but still lower. However, at the level of upper secondary or post education and lower secondary education, the differences, between the level of competencies acquired by graduates and the level required by the labor market, are greater. The main cause of this gap between employee and employer perceptions, could be the fact that most academic programs neglect the development of their students' soft skills, and thus, students lack the required competencies (Orlando, 2013; Robles, 2012; Nusrat and Sultana, 2019). Recently Succi and Canovi (2019) found that the large majority of employers $(60.2 \%)$ agreed that students are not well or very well prepared by higher education institutions. The differences highlighted could help education units to reconsider the importance of soft skills and include them in their curricula, leading to the acquirement of skills in levels, closer to employers' standards (Teng et al., 2019).

A reason for the non inclusion of soft skills in the curricula, could be the fact be that soft skills development are not part of their educational approach and strategies. Higher education managers seem not to believe in the high importance of soft skills for students' future employment (i.e., higher education institutions have curricula that focus mainly on hard skills). This view needs to change though. Higher education institutions curricula need to be reformed, by incorporating alternative approaches, in terms of enhancing soft skills. The study program, learning methods, teaching content and assessment process should be oriented toward the development of students' soft skills (Sethi, 2018; Anthony and Garner, 2016). In addition, experiences through internships or apprenticeships during the study years, would effectively boost students' soft skills (Jackson et al., 2016). Soft skills seem to be more easily and faster developed and acquired at earlier life stages, and before the entry into the labor market (Robles, 2012). Similarly, researchers have highlighted the need for a curriculum reform in primary and secondary education (Cravens et al., 2011; Forlin, 2010). Specifically, they stressed the importance of curricula being well-balanced and more vocationally challenging (Toremen et al. 2009). Curriculum content should provide the "right" knowledge to the student (Ibrahim et al., 2017), emphasizing skills development (Bunyi, 2013).

Another cause of the soft skills gap between employees and employers perceptions, is that some employees may underestimate the value of soft skills proficiency and be reluctant to develop them. The findings of this study could help students, before entering the labor market, to understand their deficiencies and motivate them to improve their soft skills. People with soft skills proficiency can not only effectively fit into their working environment and achieve personal and organizational goals, but also advance their academic knowledge through graduate, postgraduate or doctoral studies (OECD, 2015). In addition, employees should be encouraged to self-assess their skills effectively, so as to have more accurate perceptions of their own skills, which can then be applied throughout their working lives (Saunders and Zuzel, 2010). In this way, employees could perform a better self-evaluation, and employers could understand employees' reactions and way of thinking regarding their soft skills. Deatiled and focused on skills feedback from supervisors, would help employees to compare their self-evaluation to employer evaluations and focus on readjusting their own inflated views to align with the more realistic evaluations of their supervisors (Mayo, 2016).

On the other hand, employers should support employees who have had fewer educational opportunities to develop their soft skills in their previous working environment. Firms should provide development opportunities through seminars, job rotation, coaching, 
sensitivity training or experiential learning, to further employees' soft skills. However, micro firms (accounting for $96.2 \%$ of the Greek business sector and employing one to ten employees) do not have such financial or technical capability, and their employees have fewer opportunities to acquire new skills.

Finally, employers should reconsider their evaluation of employees' soft skills, so as to get closer to the existing reality and to form more reasonable expectations. In addition, employers' perceptions of employees' soft skills, may not reflect employees' real abilities and may be biased by ignorance, personal relations or stereotypes (Turek and PerekBialas, 2013). Employers especially in micro firms lack specific knowledge in conducting employee skills' evaluations, making training necessary.

\section{Limitations and Future Research Directions}

Despite this study's contributions, some limitations still exist and should be taken into consideration for future research. The present study highlighted the importance of soft skills, as they determine an applicant's employability, job performance and career prospects. However, it is quite difficult to determine exactly which soft skills are needed in each workplace and at which level. Different employers require different skills, which depend on the job position, the employment sector, the organizational or social culture, the size of the firm and the market orientation of the organization (Atkins, 1999; Mitchell et al., 2010; Cox and King, 2006). The list of soft skills, used in studies (including the present study), deemed critical for workforce success. This list is not shared and diverges from one study to another in terms of the number of soft skills, the terminology and definitions. Future research should be conducted to standardize soft skills measurement and establish common definitions.

The present study focuses on Greece, which is characterized by a high rate of youth unemployment (38.5\% as of $12 / 2018)$, an important contribution of the services sector to the country's economy and an educational system with gaps in terms of soft skills development (Statista Official Website). The fastest growing and largest part of the country's economy is the services sector, which accounts for $68.88 \%$ of GDP and contributes to employment, by employing $72.57 \%$ of the working population (Statista Official Website). Soft skills are also core to the success of the services sector. The increasing emphasis on customer needs, customer satisfaction and personalized services, has further underscored the need for this kind of skills. In addition, the Greek educational system, although acknowledging that students should be prepared for a demanding local and international labor market, seems considerably confused over how soft skills should be defined and taught. Due to the country-specific focus, the current conclusions cannot be generalized to other countries, though. Future studies should seek to explore a broader population and to conduct comparative research across different countries.

In addition, the present study examines and compares employees' and employers' perceived level of soft skills in a variety of industries. The specific nature of the work of the employees having participated in the survey, might have influenced the results of this study. The level of employees' soft skills proficiency may differ between office and manufacturing workers, considering the different levels of customer service provision and customer interaction.

Another limitation, is the level of data subjectivity, as the data stem from self-reported scales. Soft skills may be assessed in a subjective way, in the absence of an objective test, 
to evaluate all the different soft skills possessed by employees and required by employers (Chamorro-Premuzic et al., 2010). The common method bias problem could be avoided in the future, by using objective data in addition to subjective data.

\section{References}

AbuJbara, N. and Worley, J.A. (2018), "Leading toward new horizons with soft skills", On the Horizon, Vol. 26 No. 3, pp. 247-259.

Ahmad, S.B.S. (2013), "Soft skills level of Malaysian students at a tertiary institution: a comparative case study based on gender, area of residence and type of schools?", International Journal of Asian Social Science, Vol. 3 No. 9, pp. 1929-1937.

Albandea, I. and Giret, J.-F. (2018), "The effect of soft skills on French post-secondary graduates' earnings", International Journal of Manpower, Vol. 39 No. 6, pp. 782-799.

Andrews, J. and Higson, H. (2008), “Graduate Employability, 'Soft Skills' Versus 'Hard' Business Knowledge: A European Study”, Higher Education in Europe, Vol. 33 No. 4, pp. 411-420.

Anthony, S. and Garner, B. (2016), "Teaching soft skills to business students: an analysis of multiple pedagogical methods", Business and Professional Communication Quarterly, Vol. 79 No. 3, pp. 360-370.

Aring, M. (2012), "Youth and skills: Putting education to work", EFA Global Monitoring Report.

Arraj, H.A. (2018), "Professionalism among employees in Lebanon: the Lebanese University", World Journal of Entrepreneurship, Management and Sustainable Development, Vol. 14 No. 4, pp. 385-392.

Atkins, M.J. (1999), "Oven-ready and self-basting: Taking stock of employability skills", Teaching in Higher Education, Vol. 4 No. 2, pp. 1356-2517.

Azim, S., Gale, A., Lawlor-Wright, T., Kirkham, R., Khan, A. and Alam, M. (2010), "The importance of soft skills in complex projects", International Journal of Managing Projects in Business, Vol. 3 No. 3, pp. 387-401.

Bailly, F. and Léné, A. (2012), "The personification of the service labour process and the rise of soft skills: a French case study", Employee Relation, Vol. 35 No. 1, pp. 79-97.

Bak, O., Jordan, C. and Midgley, J. (2019), "The adoption of soft skills in supply chain and understanding their current role in supply chain management skills agenda: A UK perspective", Benchmarking: An International Journal, Vol. 26 No. 3, p. 1063-1079.

Balaji, K.V.A. and Somashekar, P. (2009), "A Comparative study of soft skills among engineers", The IUP Journal of Soft Skills, Vol. III No. 3 \& 4, pp. 50-57.

Balcar, J. (2016), "Is it better to invest in hard or soft skills?", The Economic and Labour Relations Review, available at: https://doi.org/10.1177/1035304616674613

Bancino, R. and Zevalkink, C. (2007), "Soft skills: The new curriculum for hard-core technical professionals", Techniques: Connecting Education and Careers, Vol. 82 No. 5 pp. 20-22. 
Bartlett, W. (2013), "Skill Mismatch, Education Systems, and Labour Markets in EU Neighbourhood Policy Countries", working Paper, The Sharing Knowledge Assets: Interregionally Cohesive Neighborhoods.

Blades, R., Fauth, B. and Gibb, J. (2012), “Measuring employability skills: A rapid review to inform development of tools for project evaluation", available at: http://britishcouncil.org/voices-magazine/china-creating-workforce-no-soft-skills (accessed 28 April 2018).

Brunello, G. and Rocco, L. (2017), "The effects of vocational education on adult skills, employment and wages: What can we learn from PIAAC?", SERIEs, Vol. 8 No. 4, pp. 315343.

Brungardt, C. (2011), "The intersection between soft skills development and leadership Education", Journal of Leadership Education, Vol. 10 No. 1, pp. 1-21.

Bunyi, G.W. (2013), "The quest for quality education: the case of curriculum innovations in Kenya", European Journal of Training and Development, Vol. 37 No. 7, pp. 678-691.

Chamorro-Premuzic, T., Arteche, A., Bremmer, A.J., Greven, C. and Furnham, A. (2010), "Soft skills in higher education: Importance and improvement ratings as a function of individual differences and academic performance", Educational Psychology: An International Journal of Experimental Educational Psychology, Vol. 30 No. 2, pp. 221-241.

Chan, J. (2015), "Is China creating a workforce with no soft skills? British council", availableat:https://www.britishcouncil.org/voices-magazine/china-creating-workforceno-soft-skills (accessed 1 August 2019).

Christou, E. (2002), "Revisiting competencies for hospitality management: contemporary views of the stakeholders", Journal of Hospitality \& Tourism Education, Vol. 14 No.1, pp. 25-32.

Cimatti, B. (2016), “Definition, Development, Assessment of Soft Skills and their Role for the Quality of Organizations and Enterprises", International Journal for Quality Research, Vol. 10 No. 1, pp. 97-130.

Clarke, M. (2017), "Rethinking Graduate Employability: The Role of Capital, Individual Attributes and Context", Studies in Higher Education, Vol. 43 No. 11, pp. 1923-1937.

Cox, S. and King, D. (2006), "Skill sets: an approach to embed employability in course design", Education + Training, Vol. 48 No. 4, pp. 262-274.

Cravens, X.C., Chu, H. and Zhao, Q. (2011), "Defining School Effectiveness in the Reform for Quality-Oriented Education", The Impact and Transformation of Education Policy in China, Vol. 15, pp. 153-185.

de Villiers, R. (2010), "The incorporation of soft skills into accounting curricula: preparing accounting graduates for their unpredictable futures", Meditari Accountancy Research, Vol. 18 No. 2, pp. 1-22.

Deming, D. (2015), “The growing importance of social skills in the labor market”, working Paper 21473, Cambridge University, MA: National Bureau of Economic Research( NBER), Cambridge. 
Finch, D.J., Hamilton, L.K., Baldwin, R. and Zehner, M. (2013), "An exploratory study of factors affecting undergraduate employability", Education + Training, Vol. 55 No. 7, pp. $681-704$.

Forlin, C. (2010), "Developing and implementing quality inclusive education in Hong Kong, implications for teacher education", Journal of Research in Special Educational Needs, Vol. 10 No. 1, pp. 177-184.

Freudenberg, B., Brimble, M. and Cameron, C. (2011), "WIL and generic skill development: the development of business students' generic skills through work-integrated learning", Asia-Pacific Journal of Cooperative Education, Vol. 12 No. 2, pp. 79-93.

Gewertz, C. (2007), “Soft skills in big demand”, Education Week, Vol. 26 No. 40, pp. 25-27.

Gibb, S. (2014), "Soft skills assessment: theory development and the research agenda", International Journal of Lifelong Education, Vol. 33 No. 4, pp. 455- 471.

Grisi, C.G.A., (2014), "Soft Skills: a close link between enterprises and ethics. Speech at "Soft Skills and their role in employability - New perspectives in teaching, assessment and certification", workshop in Bertinoro, FC, Italy.

Hawkins, P. (1999), “The art of building windmills", Liverpool: Graduate IntEmployment Unit.

Heckman, J.J. and Kautz, T. (2012), "Hard evidence on soft skills”, Labour Economics, Vol. 19 No. 4, pp. 451-464.

Heckman, J.J. and Rubinstein, Y. (2001), “The Importance of Noncognitive Skills: Lessons from the GED Testing Program", American Economic Review, Vol. 91 No. 2, pp. 145-149.

Hurrell, S.A. (2016), "Rethinking the Soft Skills Deficit Blame Game: Employers, Skills Withdrawal and the Reporting of Soft Skills Gaps", Human Relations, Vol. 69 No. 3, pp. 605-628.

Ibrahim, Y., Arshad, R. and Salleh, D. (2017), "Stakeholder perceptions of secondary education quality in Sokoto State, Nigeria", Quality Assurance in Education, Vol. 25 No. 2, pp.248-267.

Ibrahim, R., Boerhannoeddin, A. and Bakare, K.K. (2017), "The effect of soft skills and training methodology on employee performance", European Journal of Training and Development, Vol. 41 No. 4, pp. 388-406.

Ilias, A., Razak, M.Z.A., Yunus, N.K.Y. and Razak, S.F.F.A. (2012), “How accounting students perceived towards teamwork skills", Journal of Education and Vocational Research, Vol. 3 No. 12, pp. 387-398.

Ismail, I., Ahmad, A.R. and Awang, M.M. (2017), "A Study of Soft Skills among Polytechnic Students”, Open Journal of Social Sciences, Vol. 5, pp. 295-231.

Jackson, K., Lower, C.L. and Rudman, J.W. (2016), “The Crossroads between Workforce and Education", Perspectives in Health Information Management, Vol. 5 No. 1, pp. 1-11.

Jolly, S.S. (2012), "Developing soft skills for enhancing employability of engineering graduates", International Journal of Engineering and Management Research, Vol. 2 No. 5, pp. 54-56. 
Kato, T. and Kodama, N. (2017), "Women in the Workplace and Management Practices: Theory and Evidence", IZA - Institute of Labor Economics, DP No. 10788, available at: http://ftp.iza.org/dp10788.pdf

Klibi, M.F. and Oussii, A.A. (2013), "Skills and attributes needed for success in accounting career: do employers' expectations fit with students' perceptions? Evidence from Tunisia", International Journal of Business and Management, Vol. 8 No. 8, pp. 118-132.

Knight, P.T. and Yorke, M. (2002), "Employability through the curriculum", Tertiary Education and Management, Vol. 8 No. 4, pp. 261-276.

Laker, D.R. and Powell, J.L. (2011), “The differences between hard and soft skills and their relative impact on training transfer", Human Resource Development Quarterly, Vol. 22 No. 1, pp. 111-122.

Lippman, L., Ryberg, R., Carney, R., and Moore, K.A. (2015), "Key "Soft Skills" that foster Youth Workforce Success: Toward a Consensus Across Fields", available at: https://www.childtrends.org/publications/key-soft-skills-that-foster-youth-workforcesuccess-toward-a-consensus-across-fields.

Lundeberg, M.A., Fox, P.W., and Punccohar, J. (1994), "Highly confident but wrong: Gender differences and similarities in confidence judgments", Journal of Educational Psychology, Vol. 86 No. 1, pp. 114-121.

Masson, J. R. and Fetsi, A. (2007). "Human Capital and Education Reforms in the Western Balkans", in Fetsi, A. (ed), Labour Markets in the Western Balkans: Challenges for the Future, Office for Official Publications of the European Communities, Luxembourg, pp. 71110.

Mayo, M. (2016), "The gender gap in feedback and self-perception", available at: https://hbr.org/2016/08/the-gender-gap-in-feedback-and-self-perception.

McKinsey and Company (2012), "The state of human capital 2012: false summit - why the human capital function still has far to go", Research Report No. R-1501-12-RR, McKinsey and Company.

McMurray, S., Dutton, M., McQuaid, R. and Richard, A. (2016), "Employer demands from business graduates", Education + Training, Vol. 58 No. 1, pp. 112-132.

Mitchell, G.W., Skinner, L.B. and White, B.J. (2010), "Essential soft skills for success in the twenty-first century workforce as perceived by business educators", The Journal of Research in Business Education, Vol. 52 No. 1, p. 43.

Moss, P. and Tilly, C. (2001), "Stories Employers Tell: Race, Skill, and Hiring in America", Russell Sage Foundation.

Muzio, E., Fisher, D.J., Thomas, E. R. and Peters, V. (2007), "Soft skills quantification (SSQ) for project manager competencies: improved approach to incorporate uncertainty using Bayesian networks", Project Management Journal, Vol. 38 No. 2, pp. 30-38.

Nauffal, D. and Skulte-Ouaiss, J. (2018), "Quality higher education drives employability in the Middle East", Education + Training, Vol. 60 No. 9, pp. 1057-1069.

Nickson. D., Warhurst, C., Commander, J., Hurrell, S. and Cullen, A.M. (2012), "Soft skills and employability: evidence from UK Retail", Economic and Industrial Democracy, Vol. 3 No. 1, pp. 62-81. 
Nilsson, S. (2010), "Enhancing employability: The perspectives of engineering graduates", Education + Training, Vol. 52 No. 6/7, pp. 540-551.

Nunnally, J.C. (1978), “ Psychometric theory” , in 2nd (Ed) , McGraw-Hill ,New York .

Nusrat, M. and Sultana, N. (2019), "Soft skills for sustainable employment of business graduates of Bangladesh", Higher Education, Skills and Work-Based Learning, Vol. 9 No. 3, pp. 264-278.

OECD, PISA (2015), Results (Volume V): Collaborative Problem Solving, http://www.oecd.org/education/pisa-2015-results-volume-v-9789264285521-en.htm

Oladokun, S.O. and Gbadegesin, J.T. (2017), "Adequacy of core knowledge and soft skills in the performance of professional employees of real estate firms in Nigeria", Property Management, Vol. 35 No. 2, pp.132-149.

Orlando P. (2013), "Soft Skills: From University to the Work Environment. Analysis of a Survey of Graduates in Portugal", Regional and Sectoral Economic Studies, Vol. 13 No. 1, pp. 105-118.

Pandey, M. and Pandey, P. (2015), "Global employability of unemployed youth through soft skills", International Journal of Multidisciplinary Approach and Studies, Vol. 2 No. 2, pp. 73-77.

Pitan, O.S. (2017), “Graduate employees' generic skills and training needs", Higher Education, Skills and Work-Based Learning, Vol. 7 No. 3, pp. 290-303.

Poon, J. (2012), "Real estate graduates' employability skills: The perspective of human resource managers of surveying firms", Property Management, Vol. 30 No. 5, pp. 416-434.

Ramlan, R. and Ngah, S. (2015), "Student perception on the importance of soft skills for education and employment", PEOPLE: International Journal of Social Sciences, International Journal of Social Sciences, Vol. 1 No. 1, pp. 696-708 .

Ramli, A., Nawawi, R., Poh, M. and Chun, P. (2010), "Employees' Perception of Employability Skills Needed in Todays Workforce among Physiotherapy Graduates", Procedia Social and Behavioral Sciences, Vol. 7 No. C, pp. 455-463.

Rao, M.S. (2014), "Enhancing employability in engineering and management students through soft skills", Industrial and Commercial Training, Vol. 46 No. 1, pp.42-48.

Robles, M. (2012), "Executive Perceptions of the Top 10 Soft Skills Needed in Today's Workplace”, Business Communication Quarterly, Vol. 75 No. 4, pp. 453-465.

Saunders, V. and Zuzel, K. (2010), "Evaluating Employability Skills: Employer and Student Perceptions”, Bioscience Education, Vol. 15 No. 1, pp. 1-15.

Seetha, N. (2014), "Are Soft skills important in the workplace? A preliminary investigation in Malaysia", International Journal of Academic Research in Business and Social Sciences, Vol. 4 No. 4, pp. 44-56.

Sethi, D. (2018), "Self-facilitation framework for developing soft skills - FSIAR", Development and Learning in Organizations: An International Journal, Vol. 32 No. 6, pp. 57. 
Singh, A. and Jaykumar, P. (2019), "On the road to consensus: key soft skills required for youth employment in the service sector", Worldwide Hospitality and Tourism Themes, Vol. 11 No. 1, pp. 10-24.

Stapleton, K. (2017), "Inside the world's largest higher education boom", available at: https://www.statista.com

Stevens, M.J. and Campion, M.A. (1999), "Staffing work teams: development and validation of a selection test for teamwork settings", Journal of Management, Vol. 25 No. 2, pp. 207228.

Succi, C. and Canovi, M. (2019), "Soft skills to enhance graduate employability: comparing students and employers' perceptions", Studies in Higher Education, https://doi.org/10.1080/03075079.2019.1585420.

Succi, C. and Wieandt, M. (2019), "Walk the talk: soft skills' assessment of graduates", European Journal of Management and Business Economics, Vol. 28 No. 2, pp. 114-125.

Sustein, C.R. and Hastie, R. (2014), "Great teams need social intelligence, equal participation and more women", Harvard Business Review, available at: https://www.linkedin.com/pulse/forget-myers-briggs-b build-great-team-focus-factorc-cass-sunstein?trk=prof-pos.

Swiatek, J. (2000), "Student and Employer Expectation", available at: www.ineer.org/Events/ICEE2000/proceedings/title_index.htm (accessed January 2008).

Taylor, E. (2016), "Investigating the perception of stakeholders on soft skills development of students: Evidence from South Africa", Interdisciplinary Journal of e-Skills and Life Long Learning, Vol. 12 No. 1, pp. 1-18.

Tempone, I., Kavanagh, M., Segal, N., Hancock, P., Howieson, B. and Kent, J. (2012), "Desirable generic attributes for accounting graduates into the twenty-first century: the views of employers", Accounting Research Journal, Vol. 25 No. 1, pp. 41-55.

Teng, W., Ma, C., Pahlevansharif, S. and Turner, J.J. (2019), "Graduate readiness for the employment market of the 4th industrial revolution: The development of soft employability skills", Education + Training, available at: https://doi.org/10.1108/ET-072018-0154.

Toremen, F., Karakuş, M. and Yasan, T. (2009), "Total quality management practices in Turkish primary schools", Quality Assurance in Education, Vol. 17 No. 1, pp.30-44.

Truong, H. and Laura, R. (2015), "Essential Soft Skills for Successful Business Graduates in Vietnam", Sociology Study, Vol. 5 No. 10, pp. 759-763.

Turek, K. and Perek-Bialas, J. (2013), "The role of employers opinions about skills and productivity of older workers: example of Poland", Employee Relations, Vol. 35 No. 6, pp. 648-664.

US Chamber of Commerce Foundation (2016), "Bridging the Soft Skills Gap", available at: https://www.uschamberfoundation.org/reports/soft-skills-gap. 
Van den Broeck, A., Schreurs, B., Guenter, H. and Emmerik I.J.H. (2015), "Skill utilization and well-being: a cross-level story of day-to-day fluctuations and personal intrinsic values", Work \& Stress, Vol. 29 No. 3, pp. 306-323.

Van Emmerik, I.J.H., Schreurs, B., De Cuyper, N., Jawahar, I.M., and Peeters, M.C.W. (2012), "The Route to Employability: Examining Resources and the Mediating Role of Motivation", Career Development International, Vol. 17 No. 2, pp. 104-19.

Wesley, S.C., Jackson, V.P. and Lee, M. (2017), "The perceived importance of core soft skills between retailing and tourism management students, faculty and businesses", Employee Relations, Vol. 39 No. 1, pp. 79-99.

Wickramasinghe, V. and Perera, L. (2010), "Graduates', university lecturers' and employers' perceptions towards employability skills", Education + Training, Vol. 52 No. 3, pp. 226-244.

Ziegler, R. (2007), "Student perceptions of "soft" skills in mechanical engineering", paper presented at the International Conference on Engineering Education - ICEE 2007, September $3-7$, Coimbra, Portugal. 